we have $d x=e_{i} \omega^{i}, d e_{i}=e_{j} \omega_{i}^{j}+h_{i j} \omega^{j}, \omega_{i}^{j}+\omega_{j}^{i}=0, d h_{i j}=-\sum_{k} B_{i j, k l} e_{k} \omega^{i}+$ $+h_{k j} \omega_{i}^{k}+h_{i k} \omega_{j}^{k}$, where (10) holds, and then $\left\langle e_{i}, e_{j}\right\rangle,\left\langle e_{i}, h_{k l}\right\rangle$ and $\left\langle h_{i j}, h_{k l}\right\rangle$ conserve their values, respectively $\delta_{i j}, 0$ and $B_{i j, k l}$, as is easy to see by differentiation.

In the case of completeriess of $M^{m}$ the universal covering group for all these inner motions is $O(m+1)$, which acts on $E^{n}$ by rotations with centre $c$, and $M^{m}$ is its orbit in $S^{n \rightarrow 1} \subset E^{n}$. So the Theorem is proved.

\title{
REFERENCES
}

1. Синюков Н. С. Геодезические отображения римановых пространств. М., Наука, 1979 (Гл. II, § 3).

2. Szabí, Z. I. // J. Differ. Geometry, 1982, 17, 531-582.

3. Ferus, D. // Math. Ann., 1980, 247, 81-93.

4. Deprez, J. // J. of Geometry, 1985, 25, 192-200.

5. Chen, B.-Y. Geometry of Submanifolds. New-York, Marcel Dekker. Inc., 1973.

6. Nomizu, K. // Tõhoku Math. J., 1968, 20, 46-59.

7. Takagi, H. // Tōhoku Math. J., 1972, 24, 105-108.

8. Deprez, J. // Rend. Semin. mat. Univ. e politecn. Torino, 1987, 44, 303-316.

9. Lumiste, U. // Acta et comm. Univ. Tartuensis, 1988, 803, 79-94.

10. Borüvka, O. // C. r. Acad. sci., 1928, 187, 334-336.

11. Blanuša, D. // Glas. mat.-fiz. i astron., 1953, 8, 81-114.

12. Солодовников А. С. // Тр. семин. по вект. и тенз. анал., 1961, XI, 293-308.

13. Муллари Р. Р. // Уч. зап. Тартуск. ун-та, 1962, 129, 62-73.

14. Евтушик $\mathcal{I}$. E. и др. Дифференциально-геометрические структуры на многообразиях. Пробл. геом. Т. 9. М., ВИНИТИ АН СССР, 1979.

Tartu State University

Received

Jan. 27,1989

Proc. Estonian Acad. Sci. Phys. Math., 1989, 38, N 4, 457-459

удК 537.226 .4

P. KONSIN and T. ORD

\section{CHANGE OF THE ORDER OF FERROELECTRIC PHASE TRANSITION UNDER HYDROSTATIC PRESSURE}

\author{
P. KONSIN, $T$, ORD, SENJETTELEKTRILISE FAASISIIRDE LIIGI MUUTUMINE HODROSTAA- \\ TILISE ROHU TOIMEL \\ П. КОНСИН, Т. ЭРД. ИЗМЕНЕНИЕ РОДА СЕГНЕТОЭЛЕКТРИЧЕСКОГО ФАЗОВОГО ПЕРЕ- \\ ХОДА С ГИДРОСТАТИЧЕСКИМ ДАВЛЕНИЕМ
}

\section{(Presented by V. Hizhnyakov)}

In this paper, the possibilities of changing the order of ferroelectric phase transition under high hydrostatic pressure have been investigated on the phenomenological level. Such effect or a corresponding tendency has been found, e.g., in the monocrystals $\mathrm{BaTiO}_{3}\left[{ }^{1-3}\right]$, SbSI $\left.{ }^{4-7}\right]$, KDP $\left[{ }^{8-11}\right], \mathrm{Sn}_{2} \mathrm{P}_{2} \mathrm{~S}_{6}\left[{ }^{12}\right]$, TGSe [13-15].

Let us start from the expansion of the free energy in powers of the order parameter $y$ and the strain $\varepsilon$ for a liquid-like model of a ferroelectric in which, besides the standard terms, the terms with the coefficients $h, f$ and $w$ have been taken into account:

$$
F=\alpha(T) y^{2}+\beta y^{4}+\gamma y^{6}+\frac{1}{2} c \varepsilon^{2}+g \varepsilon y^{2}+\frac{1}{2} h \varepsilon^{2} y^{2}+f \varepsilon y^{4}+\frac{1}{3} w \varepsilon^{3} .
$$

Here $c$ and $g$ are the elastic and electrostrictive constants. 
A number of possibilities of changing the order of phase transition, arising as special cases from the free energy (1), have been considered in $\left.{ }^{16]}\right]: c \neq 0, h \neq 0, g=f=w=0 ; \quad c \neq 0, \quad g \neq 0, w \neq 0, h=f=0 ; c \neq 0$, $g \neq 0, h \neq 0, f=w=0$; also $c \neq 0, g \neq 0$ with the account of the term $\sim \varepsilon^{4}$ at $h=f=w=0$, and $c \neq 0$ with the account of the term $\sim \varepsilon y^{3}$ at $g=h=f=w=0$. The meaning of the $\varepsilon^{3}-$ and $y^{2} \varepsilon^{2}$-type terms as applied to $\mathrm{BaTiO}_{3}$, and of the $y^{2} \varepsilon^{2}$-type term as applied to SbSI with the account of space anisotropy within the frames of realizing symmetries has been discussed in $\left[{ }^{3,17}\right]$, respectively.

In the present work, the conditions more general in comparison with those derived in $\left[{ }^{16}\right]$ have been obtained, which determine the change of the order of structural phase transition under the action of hydrostatic pressure.

By means of the transformation ( $p$ is the hydrostatic pressure)

$$
\Phi(p)=F(\varepsilon)+\varepsilon p
$$

we get from the thermodynamic potential $F(\varepsilon)$ the potential $\Phi(p)$, whereby the relation between $p$ and $\varepsilon$ has been determined as

$$
p=-\partial F(\varepsilon) / \partial \varepsilon \text {. }
$$

For a mechanically free crystal $p=0$. From Equation (3) we find

$$
\varepsilon=-\frac{c+h y^{2}}{2 w} \pm\left[\left(\frac{c+h y^{2}}{2 w}\right)^{2}-\frac{g y^{2}+f y^{4}+p}{w}\right]^{1 / 2} .
$$

In case $\left(c+h y^{2}\right)^{2} \gg 4\left|w\left(g y^{2}+f y^{4}+p\right)\right|$ a solution which has a physical meaning may be written in the form

$$
\varepsilon \approx-\frac{g y^{2}+f y^{4}+p}{c+h y^{2}}\left[1+\frac{w\left(g y^{2}+f y^{4}+p\right)}{\left(c+h y^{2}\right)^{2}}\right] .
$$

Expanding (5) in powers of the nonequilibrium order parameter $y$ into series, we have

$$
\begin{gathered}
\varepsilon=-\frac{1}{c}\left\{\left(1+\frac{w}{c^{2}} p\right) p+\left[g-\frac{1}{c}\left(h-\frac{2 w g}{c}\right) p\right] y^{2}+\right. \\
\left.\left.+\left[f-\frac{g}{c}^{\prime} h-\frac{w g}{c}\right)\right] y^{4}\right\} .
\end{gathered}
$$

As a result, on the basis of (1), (2), (6) we, get (the terms exceeding the precision of primary expansion (1) have been omitted)

$$
\Phi=\tilde{\alpha}(T, p) y^{2}+\tilde{\beta}(p) y^{4}+\tilde{\gamma} y^{6}-\frac{1}{2 c} p^{2}-\frac{w}{3 c^{3}} p^{3},
$$

where

$$
\begin{aligned}
& \tilde{\alpha}(T, p)=\alpha(T)-\frac{1}{c}\left[g-\frac{1}{c}\left(\frac{h}{2}-\frac{w g}{c}\right) p\right] p, \\
& \tilde{\beta}(p)=\beta-\frac{g^{2}}{2 c}-\frac{1}{c}\left[f-\frac{g}{c}\left(h-\frac{w g}{c}\right)\right] p, \\
& \tilde{\gamma}=\gamma-\frac{g}{c}\left[f-\frac{g}{c}\left(\frac{h}{2}-\frac{w g}{3 c}\right)\right] .
\end{aligned}
$$

It follows from the dependence of $\tilde{\beta}$ on $p$ that sufficiently high external pressure may cause the change of the order of phase transition. 
If the first-order phase transition takes place in the system at $p=0$ $(\tilde{\beta}(0)<0, \tilde{\gamma}>0)$, then in case $R<0, p>p_{c r}$ the second-order transition occurs. Here

$$
R=\frac{1}{c}\left[f-\frac{g}{c}\left(h-\frac{w g}{c}\right)\right],
$$

while $p_{\text {cr }}$ determined from the condition $\tilde{\beta}\left(p_{c r}\right)=0$ equals

$$
p_{c r}=\tilde{\beta}(0) / R \text {. }
$$

The second-order phase transition $(\tilde{\beta}(0)>0, \tilde{\gamma}>0)$ turns into the firstorder one when $R>0, \quad p>p_{\text {cr. }}$.

Hence, the hydrostatic pressure may induce both the change of the first-order ferroelectric phase transition into the second-order one and the change of the second-order transition into the first-order one depending on the values of the system parameters.

It can be seen from (8), (9) that the linear dependence of $\tilde{\beta}$ on $p$ is accompained, in general, by the nonlinear behaviour of $\tilde{\alpha}$ (proportional to the inverse dielectric susceptibility in the paraphase) under pressure. However, in case $h, w \rightarrow 0$ both $\tilde{\beta}$ and $\tilde{\alpha}$ depend on $p$ linearly. According to $\left[{ }^{1}\right]$ and $\left[{ }^{7}\right]$ the inverse dielectric susceptibility depends on $p$ approximately linearly for $\mathrm{BaTiO}_{3}$ and SbSI. This indicates that in these compounds the dependence of $\tilde{\beta}$ on $p$ is presumably mainly connected with the term from free energy (1) proportional to $f$.

For a quantitative comparison of the theory with the experimental data the tensor character of the strain must be taken into account. Pressure may influence the jump of the spontaneous polarization also through piezoeffect, by smearing the phase transition.

The authors are thankful to Prof. N. Kristoffel for useful discussions.

\section{REFERENCES}

1. Samara, G. A. // Phys. Rev., 1966, 151, № 2, 378-386.

2. Поляндов Н. Н., Струков Б. А., Мылов В. П. // ФТТ, 1967, 9, вып. 5, 14781482.

3. Clarke, R., Benguigui, L. // J. Phys. C, 1977, 10, № 11, 1963-1973.

4. Герзанич Е. И., Фридкин В. М. // Письма в ЖЭТФ, 1968, 8, вып. 10, 553-556.

5. Волк T. Р., Герзанич Е. И., Фридкин В. М. // Изв. АН СССР, 1969, 33, № 2, $346-351$.

6. Peercy, P. S. // Phys. Rev. Lett., 1975, 35, № 23, 1581-1584.

7. Samara, G. A. // Phys. Rev. B, 1978, 17, № 7, 3020-3022.

8. Schmidt, V. H., Western, A. B., Baker, A. G. // Phys. Rev. Lett., 1976, 37, № 13, $839-842$.

9. Bastie, P., Wallade, M., Vettier, G., Zeyen, C. N. E. // Phys. Rev. Lett., 1978, 40, № $5,337-340$.

10. Western, A. B., Baker, A. G., Bacon, Ch. R., Schmidt, V. H. // Phys. Rev. B, 1978, 17, № 11, 4461-4473.

11. Зисман А. Н., Качинский В. Н., Стишов С. М. // Письма в ЖЭТФ, 1980, 31, вып. 3, 172-177.

12. Тягур Ю. И., Герзанич Е. И. // Кристаллография, 1984, 29, № 5, 957-962.

13. Gesi, K., Ozawa, K. // J. Phys. Soc. Jap., 1976, 40, № 2, 599-600.

14. Yamashita, H., Takeuchi, Y., Tatsuzaki, I. // J. Phys. Soc. Jap., 1980, 49, № 5, $1874-1880$.

15. Takeuchi, Y., Yamashita, H., Tatsuzaki, I. // J. Phys. Soc. Jap., 1981, 50, № 6, 2022-2028.

16. Benguigui, L. // Phys. stat. sol. (b), 1973, 60, № 2, 835-841.

17. Teng, M K., Massot, M., Chaves, M. R., Amaral, M. H., Ziolkiewicz, S., Young, W.II Phys. stat. sol. (a), 1981, 63, № 2, 605-615.

Received March 3, 1989 